\title{
The Influence of Eastern Art on Western Architecture in the First Half of the Eleventh Century
}

\section{J. Park Harrison}

To cite this article: J. Park Harrison (1899) The Influence of Eastern Art on Western Architecture in the First Half of the Eleventh Century, Archaeological Journal, 56:1, 216-220, DOI: 10.1080/00665983.1899.10852821

To link to this article: http://dx.doi.org/10.1080/00665983.1899.10852821

电 Published online: 16 Jul 2014.

Submit your article to this journal $[\pi$

Џll Article views: 2

Q View related articles $\llbracket$ 
THE INFLUENCE OF EASTERN ART ON WESTERN ARCHITECTURE IN THE FIRST HALF OF THE FLEVENTH CENTURY.

By J. PARK HARRISON.

So little is known of the architecture of either France or England in the early part of the eleventh century, that it seemed well to give archæologists the information that has lately been obtained from the works of Baron De Caumont and M. Viollet-le-Duc, who had paid special attention to the subject.

I wish, however, first to mention what does not appear to have been at all a common belief of archæologists in this country - that Normandy, or rather Neustria, at the period when the ruthless Northmen settled down in their newly acquired territory and adopted Christianity as their religion, was without architectural remains which it was possible for them to utilise. 'The new converts then had to borrow a style for their churches, and masons to build them from Maine or some other State with which they had commercial intercourse-a circumstance that appears sufficiently to account for the "marked severity of style" and sameness of purely Norman capitals and arcades which has been observed as existing until some years after the Conquest; whilst, in this country, Anglian and Eastern love of ornament gradually affected Norman architecture, now the ruling style in England, and transformed it into a type rightly designated by French archæologists Anglo-Norman.

In Germany, Herr Luebke, in his History of $A r t,{ }^{2}$ also credits English Romanesque with a like leavening intluence-" On the conquest of England, Norman architecture began to predominate to the exclusion of the old; but the new style adopted certain elements of the earlier into its system, which thereby acquired a special national colouring." This, it will be seen, would go far to explain

1 Dietionaire Raisonnee, Vol. I, p. 138. Z History of Art. Cook's translation, Vol. i, p. 514. 
what has been considered by more than one architect of repute to be an almost impossible advance in style in a church like Waltham, though accepted as the work of Harold by Mr. Ed. Freeman, and Mr. Burges the architect employed on the restoration of the church, and confirmed by unanswerable constructive evidence from Mr. J. Arthur Reeve's measurements taken whilst the scaffolding was still standing. ${ }^{\mathrm{I}}$

To return to my subject. Baron De Caumont gives information of real importance regarding the very great improvement in art and architecture which occurred quite at the commencement of the eleventh century; and it was at this time that a colony of Greek merchants settled in Aquitaine near the abbey of St. Martin, and established an emporium at Limoges, from which as a centre the rich stuffs and art-fabrics of the East were distributed through France, and across Normandy to Rochelle for transport to the British Isles. ${ }^{2}$ This, M. Viollet-le-Duc says, was just the epoch when the building art had to find the best means of restoring the roofs and other timber work that had been destroyed by fire in the devastated provinces of France. It was not surprising then, he adds, " if the rich strangers desired to see stone vaults and cupolas introduced like those in their own land "; and it is thought they probably supplied funds for erecting the ine church of St. Front, Perigueux, with its purely Greek plan and five domes, the first large church of the Greek style known to have been erected in France, and one that has been called the sister of St. Mark's, of Venice, and for some time supposed to have been copied from it, though this was subsequently found not to have been the case. It is, however, thought that the two churches may have had a common origin, namely the church of the Twelve Apostles at Constantinople. or rather Byzantium.

The first church or "basilica" of St. Front at Perigueux, according to old records, was founded (conditur) by Chronopius, the second bishop of that name, ${ }^{3}$ circa 620 , but was ruined in the wars. The consecration

\footnotetext{
1 See The Architect, Fol. XV, p. 46, and plates.

V. le Duc, Vol. I, p. 137.
} 
of what Baron De Caumont believed to be the "second" church of St. Front, forming part of the great monastery so named, and commenced by Froterius in 984, took place in 1047. It is called in the Gallia Christiana "nova ecclesia Sancti Frontonis."

The early date of the existing church, with its five cupolas, which have of late years been almost rebuilt, appears to have been accepted by De Caumont partly from records to which M. de Verneilh had access in the Archives of the Province, and partly from the fact that the Comtesse Emma de Perigord built a chapel circa 1000, dedicated to St. Andrew, in it. She was the mother of Bishop Froterius, who died in 991.

What appears to have been part of the first church and the great monastery of St. Front was burnt in 1120 , but the cupolas would have protected the " nova ecclesia" from injury. It should be mentioned, too, when St. Front of Perigueux is said to have been the only large church of purely Greek plan with five cupolas in France, numerous domed churches were subsequently erected in Aquitaine and neighbouring provinces; these French archæologists call Byzantine, but they were all on a Latin plan. St. Astier was, perhaps, the earliest of the Latin basilican type, with five domes, three of which are over the nave, and it appears to have been built soon after. St. Front in the eleventh century. ${ }^{1}$

Domed churches on a purely Greek plan were not unknown in France at an earlier period, haring, it is believed, been introduced by Charlemagne. War, however, and rapine put an end to the Carlovingian advance in art before the end of the ninth century $\AA$ church of this period was described by Mr. J. H. Parker in the Archeologia, ${ }^{2}$ viz., the little church of Germigny sur Loire.

Oriental influence, due to the frequent intercourse between the towns in the maritime provinces of France and the East, led, Viollet-le-Duc tells us, to a markedly Greek element being introduced into French architectural ornamentation. The following are some of the principal features enumerated :-Polygonal apses ; blank arcades ;

\footnotetext{
1 A learned memoir on the supposed Byzantine character of St. Front was communicated to the Institute of British Architects in 1896. It gires reasons,

prineipaliy structural, for assigning a later date to St. Front.

${ }^{2}$ Vol. XXXVII, where see plates.
} 
pilasters decorated with friezes of flat leaves; mouldings of slight projection and several members; ornaments presenting strange combinations of flowers and foliage; leaves sharply pointed and denticulated; and sculptured fruit copied from examples in the Holy Land.

A trained eye will often detect similar Oriental features in other churches both in France and England, where unusually good work might have been expected to be met with of an early date, for the same or similar reasons that occurred at Bernay and Perigueux.' It would account for Sir Gilbert Scott expressing himself as struck with some of the foliage at Oxford cathedral as influenced by a Greek motive.

The sole example of a dome in Normandy is at Bernay, but there appear to be constructive reasons that lead M. Ruprich-Robert, the author of the important work on Norman architecture, to entertain doubts whether the rather flat cupola in the south aisle of the church was not a later addition. The monastic church itself he pronounces to be early eleventh century work, founded in 1000 by Judith, Duchess of Brittany, the wife of Duke Richard II of Normandy, and completed by him on her death. Ruprich-Robert quotes William of Jumieges as attributing to the Duke not only Bernay church, but the erection, or part erection, of several other large and equally good churches; amongst them St. Michel le Mont, Evreux, St. Taurin, and the abbey church of Fécamp, some remains of all of which, it is said, still exist.

In the appendix to a lecture in the Chapter House at Oxford ten years ago I pointed out that Ethelred II, the brother-in-law of Duke Richard II of Normandy, was engaged at the beginning of the eleventh century in building or rebuilding a minster, now part of the cathedral, towards the cost of which, he stated in his charter of 1004, that the whole of the English people contributed funds. The abbey church at Fecamp was in course of construction at this time, besides Bernay church, and bishops and abbots from the Holy Land and Syria were frequent visitors to the court of Duke Richard. The

\footnotetext{
${ }^{3}$ It is worth noticing that Ravel de Coutre. Bishop of Perigueux, who died 1013, had visited the Holy Land, and
}

that a Greek bishop may hare suggested a cupola for Ely. 
chronicles of Fontenelle (St. Wandrill's) Abbey, and Verdun Monastery, when recording this intercourse make special mention of Simeon, the Abbot of St. Catherine's on Mount Sinai, who stayed two years at Rouen and superintended the erection of a church dedicated to St. Catherine on a hill in the suburbs of that town, in which he deposited relics of the saint which he had brought with him from the East. Of this church an interesting fragment is preserved in the garden of Rouen Museum, a photograph of which was taken for me a few years ago; a typographic block has since been obtained from it (see Plate). It should be mentioned that the choir and its aisles at Bernay are older than the nave, but RuprichRobert considers the entire church to have been erected in the first half of the eleventh century. He also says that no part of it was built by a Norman architect or artist, the style of the arcades and the capitals being quite different from those in the Conqueror's church at Caen, and apparently the work of a foreigner. Yet an "extension lecturer" has recently pronounced the architecture of Bernay to be "characteristic Norman," like the Abbaye aux Hommes and Jumieges, which shows how greatly an untrained eye may mislead an archæologist who, though a ready writer, has not had the advantage of practical architectural experience.

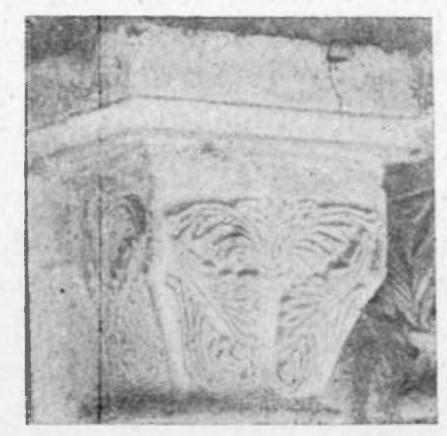

PALM CAPITAL, CHOIR-AISLE, BERNAY. 


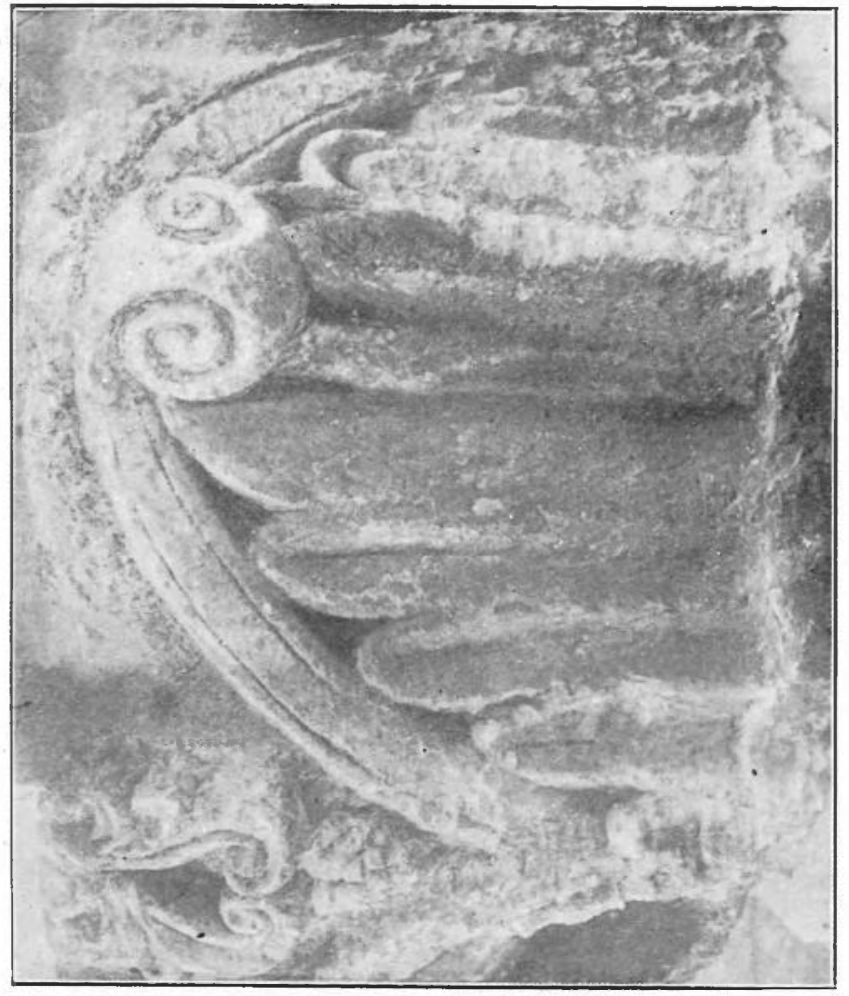

